Journal of Maternal and Child Health (2018), 3(4): 294-300

https://doi.org/10.26911/thejmch.2018.03.04.07

\title{
Prenatal Factors Associated with the Risk of Stunting: A Multilevel Analysis Evidence from Nganjuk, East Java
}

\author{
Dewi Indriani'), Yulia Lanti Retno Dewi²), Bhisma Murti'), Isna Qadrijati3) \\ 1)Masters Program in Public Health, Universitas Sebelas Maret \\ ${ }^{2)}$ Faculty of Medicine, Universitas Sebelas Maret
}

\begin{abstract}
Background: Globally, one in four children under the age of five suffers from stunting. Stunting is associated with an underdeveloped brain, with long-lasting harmful consequences, including diminished mental ability and learning capacity, poor school performance in childhood, reduced earnings and increased risks of nutrition-related chronic diseases, such as diabetes, hypertension, and obesity in future. This study aimed to analyze prenatal factors associated with the risk of stunting in Nganjuk, East Java, using a multilevel analysis.

Subjects and Method: This was an analytic observational study with a case control design. The study was conducted at 25 posyandus (integrated health posts) in Nganjuk, East Java, from June O3 to July 07, 2018. Posyandu was selected by stratified random sampling. A sample of 225 children under five was selected by fixed disease sampling, consisting of 75 stunted children and 150 normal children. The dependent variable was stunting. The independent variables were birth length, maternal height, and family size. The data were collected by questionnaire and analyzed by a multilevel logistic regression run on Stata 13.

Results: The risk of stunting increased with maternal height $<150 \mathrm{~cm}(\mathrm{~b}=2.59 ; 95 \% \mathrm{CI}=-0.75$ to 4.42; $\mathrm{p}=0.006)$, birth length $<48 \mathrm{~cm}(\mathrm{~b}=4.17 ; 95 \% \mathrm{CI}=2.19$ to $6.15 ; \mathrm{p}<0.001)$, and large family size $(\mathrm{b}=2.31 ; 95 \% \mathrm{CI}=0.34$ to $4.29 ; \mathrm{p}=0.022)$. Posyandu had a contextual effect on stunting with $\mathrm{ICC}=$ $63.39 \%$.

Conclusion: The risk of stunting increases with maternal height $<150 \mathrm{~cm}$, birth length $<48 \mathrm{~cm}$, and large family size. Posyandu has a sizeable contextual effect on stunting.
\end{abstract}

Keywords: stunting, birth length, maternal height, family size, posyandu, multilevel

\section{Correspondence:}

Dewi Indriani. Masters Program in Public Health, Universitas Sebelas Maret, Jl. Ir. Sutami 36A, Surakarta, Central Java. Email: dindriani11@gmail.com. Mobile: +6285735830730.

\section{BACKGROUND}

Malnutrition in children under five is a direct consequence of a large number of families, and lack of access to quality food and health services. Stunting is a form of malnutrition that is often faced by developing countries. Approximately $65 \%$ of the deaths of children under five are due to some forms of malnutrition and malnutrition representing one third of the burden of illness of children and mothers (Adeela and Seur, 2016). Indonesia is one of the developing countries that has a high prevalence of stunting, from 88 countries in the world, Indonesia is at the top five of stunting cases (Unicef, 2013).

Basic Health Research (2013) shows that in Indonesia, the prevalence of stunting incidence increased from 2010 to 2013 from $35.6 \%$ to $37.2 \%$. WHO recommends a stunting target of less than 20\% so it would not cause problems. Nganjuk Regency is one of the provinces in East Java which has a stunting prevalence of more than 20\%. Nganjuk regency has increased the prevalence of stunting events from 2016 
to 2017 from $22.7 \%$ to $25.9 \%$ (Nganjuk Health Office).

Prenatal factors have an important role in the incidence of stunting. Biological factors become a strong foundation in the growth of children. Growth failure is the main manifestation of malnutrition during pregnancy and in childhood which is born with low birth weight (Kramer et al, 2016). Studies in developing countries have shown that stunting depends on the condition of the population of the region (Kinyoki et al, 2016). Stunting is more common at the individual level in men than in women. Family and community levels such as maternal education, employment, family income, and basic health services affect the incidence of stunting (Hagos et al., 2017).

Stunting increases the global public health burden of contributing $45 \%$ of all under-five mortality. More than two million children under five die each year from malnutrition worldwide (Cruz et al., 2017). The other effects of stunting are disease, lack of intelligence and productivity which are certainly very beneficial for future generations (Yisak et al, 2015).

Stunting is a very important issue, so community-based interventions should be formulated and implemented to improve children's health. At the individual level, interventions must focus on educating mothers on the right basics of nutrition and the need to utilize available health services. At the community level, health systems that facilitate public health intervention include maternal and child health programs that need to be made accessible to women in rural areas. This intervention will improve the nutritional status of children under five so that the WHO global target of 2025 can be achieved (Akombi, 2017).

The foundation of the long-term food and nutrition program policy in Law No. 17 of 2007 concerns the Long Term Develop- ment Plan (RPJPN) for 2005-2025. The multi-sector approach in the development of food and nutrition includes production, processing, distribution to consumption of food with sufficient nutrition, balanced and guaranteed safety. The focus of the nutrition improvement movement is on the first 1000 days of life group at the global level called Scaling Up Nutrition (SUN) and in Indonesia, it is called the national nutrition awareness movement in order to accelerate nutritional improvement in the first 1000 days of life. Integrated health post (Posyandu) is one of the interventions in the 1000 days of life movement in monitoring the growth of children under five (Ministry of Health RI, 2012).

The researchers examined the prenatal factors that affect the incidence of Stunting in Nganjuk District, East Java Province. The purpose of this study to explain the influence of prenatal factors that affect the incidence of stunting in Nganjuk regency.

\section{SUBJECTS AND METHOD}

\section{Study Design}

This was an analytic observational study with a case control design. The study was conducted at 25 posyandus (integrated health posts) in Tanjunganom, Ngetos, Rejoso and Prambon sub-districts, Nganjuk district, East Java, from June 03 to July 07, 2018. Posyandu was selected by stratified random sampling.

\section{Population and Samples}

A sample of 225 children under five was selected by fixed disease sampling, comprising 75 stunted and 150 normal children.

\section{Study Variables}

The dependent variable was stunting. The independent variables were maternal height, birth length, family size, and posyandu. 


\section{Operational Definitions}

Maternal height was defined as the height of the mother measured at the time of the study in centimeters measured by microtoise. The measurement scale was continuous, but for the purpose of data analysis, it was transformed into dichotomous, coded o for maternal height $\geq 150 \mathrm{~cm}$ and 1 for maternal height $<150 \mathrm{~cm}$.

Birth length was defined as infant's body length measured (in $\mathrm{cm}$ ) at the time of birth. The data were taken from the maternal and child monitoring book. The measurement scale was continuous, but for the purpose of data analysis, it was transformed into dichotomous, coded o for birth length $\geq 48 \mathrm{~cm}$ and 1 for birth length $<48$ $\mathrm{cm}$.

Family size was defined as the number of household members who live and live together which is the smallest unit in the community consisting of husband and wife and their children, wife and children or father and children. The data were collected by questionnaire. The measurement scale was continuous, but for the purpose of data analysis, it was transformed into dichotomous, coded o for $<5$ and 1 for $\geq 5$.

Posyandu activities are defined as all activities carried out at the posyandu. The measuring tool used was a questionnaire. The categorical measurement scale is using parameter o for score $\geq 4$ and 1 for score $<4$.

Stunting was defined as a short stature arising from the old malnutrition that is characterized by short and very short body circumstances by measuring height of age. The body length was measured by microtoise. The measurement scale was continuous, but for the purpose of data analysis, it was transformed into dichotomous, coded o for normal children and 1 for stunting.

\section{Data Analysis}

The data analysis included univariate, bivariate, and multivariate analysis. Multivariate analysis used a multilevel logistic regression run on Stata 13.

\section{Research Ethics}

The ethichal clearance was obtained from the Research Ethics Committee at Dr. Moewardi Hospital, Surakarta, Central Java, Indonesia, with No: 110 / UN27.6 / KEPK / 2018. Research ethics of this study including inform consent, anonymity, and confidentiality.

\section{RESULTS}

\section{Univariate analysis}

The results of univariate analysis were showed in Table 1. Table 1 shows that most of the stunted children was born with birth length $<48 \mathrm{~cm}(84 \%)$, maternal height $<150$ $\mathrm{cm}(82.67 \%)$, and family size $>4$.

Table 1. Study subject characteristics

\begin{tabular}{lcccc}
\hline \multicolumn{1}{c}{ Variable } & \multicolumn{2}{c}{ Stunting } & \multicolumn{2}{c}{ Normal } \\
\cline { 2 - 5 } & $\mathbf{n}$ & $\mathbf{\%}$ & $\mathbf{n}$ & $\mathbf{\%}$ \\
\hline Maternal Height & & & \\
$<150 \mathrm{~cm}$ & 62 & 82.67 & 45 & 30 \\
$\geq 150 \mathrm{~cm}$ & 13 & 17.33 & 105 & 70 \\
Birth Length & & & & \\
$<48 \mathrm{~cm}$ & 63 & 84 & 37 & 24.67 \\
$\geq 48 \mathrm{~cm}$ & 12 & 16 & 113 & 75.33 \\
Family Size & & & & \\
$\leq 4$ & 23 & 30.67 & 124 & 82.67 \\
$>4$ & 52 & 69.39 & 26 & 17.33 \\
\hline
\end{tabular}

\section{Bivariate analysis}

The results of bivariate analysis on the effects of birth length, maternal height, and family size on stunting were showed in Table 2. Table 2 shows that the risk of stunting in child under five increased with birth length $(\mathrm{OR}=16.03 ; 95 \% \mathrm{CI}=7.80$ to 32.95; $\mathrm{p}<0.001)$, maternal height $(\mathrm{OR}=$ 11.13; $95 \% \mathrm{CI}=5.57$ to $22.24 ; \mathrm{p}<0.001)$, and family size $(\mathrm{OR}=10.78 ; 95 \% \mathrm{CI}=5.64$ to 20.61; $\mathrm{p}<0.001$ ). 
Table 2. Chi-square analysis on the effects of maternal height, birth length, and family size on stunting

\begin{tabular}{|c|c|c|c|c|c|c|c|c|}
\hline \multirow{3}{*}{$\begin{array}{l}\text { Independent } \\
\text { Variables }\end{array}$} & \multicolumn{4}{|c|}{$\begin{array}{l}\text { Stunting status } \\
\end{array}$} & \multirow{3}{*}{ OR } & \multirow{2}{*}{\multicolumn{2}{|c|}{$95 \% \mathrm{CI}$}} & \multirow{3}{*}{$\mathbf{p}$} \\
\hline & \multicolumn{2}{|c|}{ Yes $(n=75)$} & \multicolumn{2}{|c|}{$\operatorname{No}(n=150)$} & & & & \\
\hline & $\mathbf{n}$ & $\%$ & $\mathbf{n}$ & $\%$ & & Lower limit & Upper limit & \\
\hline \multicolumn{9}{|c|}{ Maternal Height } \\
\hline$<150 \mathrm{~cm}$ & 62 & 57.94 & 45 & 42.06 & 11.13 & $5 \cdot 57$ & 22.24 & $<0.001$ \\
\hline $\begin{array}{l}\geq 150 \mathrm{~cm} \\
\text { Birth Length }\end{array}$ & 13 & 11.02 & 105 & 88.98 & & & & \\
\hline$<48 \mathrm{~cm}$ & 63 & 63 & 37 & 37 & 16.03 & 7.80 & 32.95 & $<0.001$ \\
\hline $\begin{array}{l}\geq 48 \mathrm{~cm} \\
\text { Family Size }\end{array}$ & 12 & 9.6 & 113 & 90.4 & & & & \\
\hline$<5$ & 23 & 15.65 & 124 & 84.35 & 10.78 & 5.64 & 20.61 & $<0.001$ \\
\hline$\geq 5$ & 52 & 66.67 & 26 & 33.33 & & & & \\
\hline
\end{tabular}

\section{Multilevel analysis}

The results of multilevel logistic regression was showed in Table 3. Table 3 showed that there was association between maternal height and stunting. Maternal height $<150$ $\mathrm{cm}$ increased the risk of stunting in children under five $(b=2.59 ; 95 \% \mathrm{CI}=-0.75$ to $4.42 ; \mathrm{p}=0.006)$. There was an association between birth length and stunting. Birth length $<48 \mathrm{~cm}$ increased the risk of stunting $(b=4.17 ; 95 \% \mathrm{CI}=2.19$ to $6.15 ; \mathrm{p}<0.001)$. There was an association between family size and stunting. Family size $\geq 5$ increased the risk of stunting $(b=$ $2.31 ; 95 \% \mathrm{CI}=0.34$ to $4.29 ; \mathrm{p}$ 0.022). Posyandu had strong contextual effect on stunting with $\mathrm{ICC}=63.3 \%$.

Table 3. The results of multilevel logistic regression analysis on the effects of prenatal factor on stunting

\begin{tabular}{|c|c|c|c|c|}
\hline \multirow{2}{*}{ Independent Variable } & \multirow{2}{*}{$\mathbf{b}$} & \multicolumn{2}{|c|}{$95 \% \mathrm{CI}$} & \multirow{2}{*}{$\mathbf{p}$} \\
\hline & & Lower Limit & Upper Limit & \\
\hline \multicolumn{5}{|l|}{ Fixed Effect } \\
\hline Maternal Height $(<150 \mathrm{~cm})$ & 2.59 & 0.75 & 4.42 & 0.006 \\
\hline Birth Length $(<48 \mathrm{~cm})$ & 4.17 & 2.19 & 6.15 & $<0.001$ \\
\hline Family Size $(\geq 5)$ & 2.31 & 0.34 & 4.29 & 0.022 \\
\hline \multicolumn{5}{|l|}{ Random Effect } \\
\hline \multicolumn{5}{|l|}{ Posyandu Activeness } \\
\hline \multicolumn{5}{|l|}{$\mathrm{N}$ Observation $=225$} \\
\hline $\mathrm{N}$ Posyandu $=25$ & \multicolumn{4}{|c|}{ Prob $>$ chi2 $<0.001$} \\
\hline Likelihood Ratio $=-25.20$ & \multicolumn{4}{|c|}{$\mathrm{ICC}=63.39$} \\
\hline
\end{tabular}

\section{DISCUSSIONS}

\section{The effect of maternal height on stunting}

The result of this analysis showed that there was an association between maternal height and stunting, and it was statistically significant. Maternal height $<150 \mathrm{~cm}$ were more likely to have stunting than mother with normal height $(\geq 150 \mathrm{~cm})(\mathrm{b}=2.59 ; 95 \% \mathrm{CI}=$ -0.75 to $4.42 ; \mathrm{p}=0.006)$.
The result of this study is consistent with a study by Indriyani et al. (2018), which stated that there was a relationship between maternal height and birth length. Maternal height $<150 \mathrm{~cm}$ was an indirect factor that increased the incidence of stunting. Maternal height $<150 \mathrm{~cm}$ increased the likelihood of birth length $<48 \mathrm{~cm}(b=1.39$; $95 \% \mathrm{CI}=0.55$ to $2.24 ; \mathrm{p}<0.001)$. 
The result of this study supported a study of Aguayo et al. (2016), which stated that mothers who were $<145 \mathrm{~cm}$ tall would increase the incidence of stunting in infants by 2.04 times than mothers who were $\geq 145$ $\mathrm{cm}(\mathrm{b}=2.04 ; 95 \% \mathrm{CI}=1.46$ to 2.81$)$.

Maternal height was associated with children body height due to internal factors such as genetic which contributed greatly to other internal factors such as ethnicity, family, and gender (Ministry of Health RI, 2012). The result of this study was in line with a study done by Setyaningrum et al. (2017) which stated that every enhancement of $1 \mathrm{~cm}$ of maternal height, it would the growth of children nutritional status (height for age) $(b=0.43$; CI 95\% $=0.27$ to $0.58 ; \mathrm{p}<0.001)$.

A study by Amin and Hadi (2015) conducted on 252 study subjects and analyzed by a multiple logistic regression showed that maternal height contributed significantly to stunting among children aged 6-23 months. This study illustrated that genetic factors, especially maternal height had a strong effect on the incidence of stunting.

\section{The effect of birth length on stunting}

The result of this analysis showed that there was an association between birth length and stunting, and it was statistically significant. Infants with birth length $<48 \mathrm{~cm}$ increased the risk of stunting $(b=4.17 ; 95 \%$ $\mathrm{CI}=2.19$ to $6.15 ; \mathrm{p}<0.001)$. The result of this study is consistent with a study by Setyaningrum et al. (2017), which stated that birth length increased children nutritional status (height for age) $(b=0.21 ; 95 \%$ $\mathrm{CI}=0.12$ to $0.30 ; \mathrm{p}<0.001)$.

This study was in line with Rieger and Trommlerová (2016), which stated that children body heigh was affected by birth length that would always increase along with the children's age. The result of a study by Amaliah et al. (2016) stated that birth length was one of the determinants of child growth and development. Children with short birth length were 3 times more likely to have stunting.

\section{The effect of family size on stunting}

The result of analysis showed that there was an association between family size and stunting, and it was statistically significant. Family size $\geq 5$ increased the risk of stunting $(\mathrm{b}=2.31 ; 95 \% \mathrm{CI}=0.34$ to 4.29 ; $\mathrm{p}=$ 0.022). The result of this study was in line with a study by Wolde et al. (2015), which stated that the large number of family would increase the incidence of stunting $(\mathrm{b}=2.00 ; 95 \% \mathrm{CI}=0.3$ to 3.4 ).

Habyarimana et al. (2016) reported that malnutrition (stunting) determinants among children under five in Rwanda was affected by birth order. This findings showed that children who was born from large family size had higher risk to be stunted $(\mathrm{OR}=1.65, \mathrm{p}=0.002)$.

The result of this study was in line with a study done by Cruz et al. (2017), which stated that children who live in a house with other family members $(b=17.3$; $95 \% \mathrm{CI}=7.62$ to $39.12 ; \mathrm{p}=0.001$ ) and live in a house with other children for less than five years were more likely to have stunting $(\mathrm{b}=28.42 ; 95 \% \quad \mathrm{CI}=11.93$ to 67.70 ; $\mathrm{p}<0.001)$.

Children from large family size tend to get less nutrition intake, parental attention, and health care (Proverawati and Wati, 2011). Large family size would spend more money to fulfill their needs, and there would be competition and limitations in providing balanced nutritious food (Amin and Julia, 2014).

4. The effect of posyandu on stunting The result of multilevel analysis showed the score of ICC $=63.39 \%$. This indicator 
showed that Posyandu had strong contextual effect on stunting.

The result of this study was in line with a study by Sinta et al. (2017), which stated that Posyandu had a contextual effect on exclusive breastfeeding with ICC= 28.87\%. Posyandu with mandiri stratification increased the likelihood of exclusive breastfeeding rather than Posyandu with purnama and madya stratification.

Ministry of Health RI (2012), stated that Posyandu has two activities, namely main activities and optional or development activities. The main activities at the posyandu include maternal and child health, family planning, immunization, nutrition, and prevention and control of diarrhea, while the optional or development activities include the development of toddler families (DTF), Family Medicinal Plants (FMP), elderly family development (EFD), and early childhood education program (ECEP). With routine activities conducted at Posyandu, health personnel and health cadres could share information about stunting to the community, especially to the mothers.

Posyandu activities were closely related to Posyandu strata. Nganjuk has three Posyandu stratification namely madya, purnama, and mandiri. Posyandu was stratified by activeness of organization and program achievement level.

\section{REFERENCES}

$\overline{\text { Adeela A, Seur K (2016). Impact Of Mater- }}$ nal Socio-Economic Determinants On Early Childhood Stunting In Maldives: An Analysis Of Maldives Demographic Health Survey. Internasional Journal of Scientific \& Technology Research. 5:190-200

Akombi BJ, Agho KE, Hall JJ, Wali N, Renzaho AMN, Merom D (2017). Stunting, Wasting and Underweight in Sub-Saharan Africa: A Systematic Review. International Journal of Environmental Research and Public Health. 14(8). doi: 10.3390/ijerph14080863

Amin NA dan Julia M. (2014). Faktor Sosiodemografi dan Tinggi Badan Orang Tua serta Hubungannya dengan Kejadian Stunting pada Balita Usia 6-23 Bulan. Jurnal Gizi dan Dietetik Indonesia. 02(3): 170-177

Aguayo VM, Nair R, Badgaiyan N, Krishna V. (2016). Determinants of Stunting and Poor Linear Growth Inchildren Under 2 Years of Age in India: an inDepth Analysis of Maharashtra's Comprehensive Nutrition Survey. Maternal and Child Nutrition. 12(1): 121-140. doi: 10.1111/mcn.12259

Cruz LMG, Azpeiti GG, Suarez DR, Rodriquez AS, Ferrer JFL, Serra ML. (2017). Factors Associated with Stunting among Children Aged o to 59 Months from the Central Region of Mozambique. Nutriens Journal. Hal: 1-16, doi:10.3390/nu9050491

Habyarimana F, Zewotir T, Ramroop S. (2016). Key Determinants of Malnutrition of Children Under Five Years of Age in Rwanda: Simultaneous Measurement of Three Anthropometric Indices. Journal African Population Studies. 30(2): 2328-2340. doi: http://dx.doi.org/10.11564/30-2-836

Hagos S, Hailemarian D, Hanna T, Lindtjorn B (2017). Spatial Heterogeneity and Risk Factors for Stunting among Children Under Age Five in Ethiopia: A Bayesian Geo-statistical Model. Plos One Journal. 12(2). doi: https://doi.org/10.1371/journal.pone.0170785.

Indriyani E, Dewi YLR, Salimo H (2018). Biopsychosocial Determinants of Stunting in Children Under Five: A Path Analysis Evidence from the 
Border Area West Kalimantan. Journal of Maternal and Child Health, 3(2): 146-155. https://doi.org/10.26911/thejmch.2018.03.02.07

Kementerian Kesehatan RI (2012a). Pedoman Pelaksanaan Stimulasi, Deteksi dan Intervensi Dini Tumbuh Kembang Anak Ditingkat Pelayanan Kesehatan Dasar. Jakarta. (2012b). Ayo ke Posyandu Setiap Bulan. Jakarta: Promkes. (2012c). Kerangka Kebijakan Gerakan Sadar Gizi dalam Rangka Seribu Hari Kehidupan Pertama (1000 HPK) Versi 5.

Kinyoki DK, Kandala NB, Manda SO, Krainski ET, Fugltad GA, Moloney GM, Berkley JA, Noor MA (2016). Assesing Morbidity and Correlates of Wasting and Stunting among Children in Somalia using Cross-sectional Household Surveys 2007-2010. BMJ. 6:1-9. doi: 10.1136/bmjopen-2015-0o9854

Kramer M, Kupka R, Subramanian SV, Vollmer (2016). Association Between Household Unavailability of Iodized Salt and Child Growth: Evidence from 89 Demographic and Health Surveys.
The American Journal of Clinical Nutrition. 104: 1093-1099

Proverawati, Wati (2011). Ilmu Gizi untuk Keperawatan dan Gizi Kesehatan. Yogyakarta: Nuha Medika.

Riskesdas (2013). Penyajian Pokok-pokok Hasil Riset Kesehatan Dasar 2013. Badan Penelitian dan Pengembangan Kesehatan, Kementerian Kesehatan RI.

Setyaningrum TCW, Murti B, Indarto D (2017). Biopsychosocial Factors Associated with Child Growth at Ngembal Kulon Community Health Center, Kudus. Journal of Epidemiology and Public Health. 2(2): 130-140. https://doi.org/10.26911/jepublichealth.

Sinta P, Salimo H, Pamungkasari ET (2017). Multilevel Analysis on the Biososial and Economic Determinants of Exclusive Breastfeeding. Journal of Maternal and Child Health. 2(4): 356370. https://doi.org/10.26911/thejmch.2017.02.04.06

Wolde M, Berhan Y, Chala A (2015). Determinants of Underweight, Stunting and Wasting among Schoolchildren. Jurnal BMC Public Health. 15(8). doi: 10.1186/s12889-014-1337-2 